\title{
UPAYA MENINGKATKAN MOTIVASI BELAJAR SISWA DENGAN MENGGUNAKAN METODE ROLE PLAY PADA PELAJARAN IPS KELAS IV SD SWASTA XAVERIUS PADANG SIDIMPUAN
}

\author{
Wesly Silalahi
}

Surel: weslysilalahi@yahoo.com

\begin{abstract}
This research is a classroom action research (PTK) using Role Play learning method as the main target aimed to improve student's learning motivation and to know the difference of students' learning motivation using Role Play learning method with those who do not use Role Play learning method on Science subjects Social on the matter of social problems in the fourth grade of Private Elementary School Xaverius Padangsidimpuan. Thus it can be concluded that the ability of students in understanding the material social problems in Social Science lessons has been motivated in learning.
\end{abstract}

Keywords: Role Play Method, Learning Motivation, IPS Learning.

\begin{abstract}
ABSTRAK
Penelitian ini adalah penelitian tindakan kelas (PTK) dengan menggunakan metode pembelajaran Role Play sebagai sasaran utama bertujuan untuk meningkatkan motivasi belajar siswa dan untuk mengetahui perbedaan motivasi belajar siswa yang menggunakan metode pembelajaran Role Play dengan yang tidak menggunakan metode pembelajaran Role Play pada mata pelajaran Ilmu Pengetahuan Sosial pada materi masalah-masalah sosial di kelas IV SD Swasta Xaverius Padangsidimpuan. Dengan demikian dapat disimpulkan bahwa kemampuan siswa dalam memahami materi masalah-masalah sosial pada pelajaran Ilmu Pengetahuan Sosial telah termotivasi dalam belajar.
\end{abstract}

Kata Kunci: Metode Role Play, Motivasi Belajar, Pembelajaran IPS

\section{PENDAHULUAN}

Pembelajaran pengetahuan sosial pada hakikatnya sama pentingnya dengan pembelajaran pengetahuan lainnya. Pengetahuan sosial mengajarkan kepada siswa

penguasaan kecakapan hidup sehingga dapat tumbuh menjadi generasi yang kuat dan berakhlak mulia, serta dapat menjawab tuntutan perkembangan zaman. IPS seharusnya menjadi suatu pembelajaran yang disenangi peserta didik di sekolah. Seharusnya siswa termotivasi dalam melakukan kegiatan belajarnya. Kurangnya motivasi belajar siswa untuk belajar IPS dipengaruhi oleh beberapa faktor seperti suasana kelas yang ribut pada saat proses belajar mengajar berlangsung sehingga siswa sulit untuk mendengarkan penjelasan yang disampaikan oleh guru dan konsentrasi belajar juga terganggu. Oleh karena itu, guru sebagai tenaga pengajar di sekolah memiliki peranan penting untuk memberikan arahan dan menumbuhkan perhatian siswa terhadap pelajaran yang disajikan. 
Dengan memperhatikan tujuan yang dikandung pembelajaran IPS seharusnya pembelajaran IPS di Sekolah menjadi suatu kegiatan yang disenangi peserta didik. Seharusnya siswa termotivasi dalam melakukan kegiatan belajarnya. Kenyataan yang menunjukkan bahwa siswa kurang bersemangat dalam mengikuti kegiatan pembelajaran IPS adalah terlihat dari pengamatan observasi yang peneliti lakukan di lapangan yang menunjukkan bahwa motivasi belajar siswa Kelas IV SD Swasta Xaverius Padangsidimpuan T.A 2016 pada mata pelajaran IPS masih rendah ataupun kurang, karena di sebabkan guru kurang memberi motivasi atau dukungan untuk menyelesaikan materi atau soal yang d berikan dengan aktif. Dari wawancara yang dilakukan dengan guru kelas diketahui bahwa terdapat $75 \%$ siswa kurang termotivasi dan hanya $25 \%$ siswa yang termotivasi dalam belajar IPS. Sehingga siswa lebih banyak bermain daripada menyelesaikan tugas yang diberikan oleh guru.

Hal ini dikarenakan dalam proses pembelajaran guru belum menggunakan metode pembelajaran yang tepat yang dapat menarik siswa untuk belajar. Hal yang selama ini

kita temui adalah model pembelajaran yang digunakan guru masih konvensional, dimana siswa tidak begitu dilibatkan dalan kegiatan pembelajaran. Oleh sebab itulah siswa menjadi bosan dan malas ketika mengikuti jalannya proses belajar mengajar. Dalam pelajaran IPS selama ini guru cenderung hanya berceramah dan hanya memperlihatkan gambargambar pada saat pembelajaran mata pelajaran IPS yang mengakibatkan peserta didik kurang memahami pelajaran dan hanya berhayal serta merasa bosan saat pembelajaran berlangsung.

Selama ini, dalam proses belajar mengajar guru cendrung menggunakan metode ceramah yang mengakibatkan siswa menjadi bosan dan malas ketika mengikuti jalannya proses belajar mengajar pada pelajaran IPS sehingga hasil belajar siswa dalam kegiatan belajar mengajar menjadi kurang baik.

Alasan lain mengapa motivasi belajar siswa rendah pada pelajaran IPS adalah karena banyak dari kita beranggapan bahwa pelajaran IPS itu tidak terlalu penting. Mengapa kita beranggapan demikian, hal ini dikarenakan kita kurang memahami arti penting dari pembelajaran IPS itu sendiri. Seperti yang telah dikemukakan sebelumnya bahwa IPS memiliki kedudukan yang sangat penting dalam kehidupan peserta didik, karena dalam IPS

diajarkan bagaimana kita berhubungan dengan masyarakat, lingkungan, dan berhubungan dengan Tuhan.

Karena begitu pentingnya kedudukan IPS itu maka, dalam proses pembelajaran guru dianjurkan menggunakan model pembelajaran yang dapat memotivasi siswa untuk lebih aktif terlibat dalam pengalaman belajarnya. Pada mata pelajaran IPS 
peserta didik kurang termotivasi dan terrlihat pasif yang menjadikan peserta didik menjadi bosan dan jenuh pada saat pembelajaran berlangsung.

Dari hasil observasi di kelas IV SD Swasta Xaverius Padangsidimpuan Tahun Ajaran 2015/2016 yang saya lihat, proses pembelajaran IPS khususnya kurang menarik dan kurang bervariasi yang mengakibatkan peserta didik kurang termotivasi dalam belajar. Hal ini mungkin disebabkan karena kurangnya kemampuan guru dalam menggunakan metode pembelajaran karena guru masih cenderung

menggunakan metode yang konvensional atau ceramah dalam proses belajar mengajar.

Untuk mengatasi hal tersebut maka harus dicari alternatif pemecahan masalahnya. Salah satunya dengan cara menggunakan metode Role Play (bermain peran). Metode Role Play (bermain peran) ini merupakan kegiatan pembelajaran yang menekankan pada kemampuan penampilan peserta didik untuk memerankan status dan fungsi pihakpihak lain yang terdapat pada kehidupan nyata.Metode ini dapat membuat peserta didik menjadi lebih aktif dan termotivasi untuk menganalisis dan memahami situasi serta memikirkan masalah yang terjadi dalam bermain peran.

Oleh karena itu, berdasarkan pemaparan permasalahan tersebut saya merasa tertarik mengangkat judul "Upaya Meningkatkan Motivasi Belajar Siswa Dengan
Menggunakan Metode Role Play Pada Mata Pelajaran IPS Di Kelas IV SD Swasta Xaverius Padangsidimpuan Tahun Ajaran 2015/2016".

Djamarah (dalam Dirman 2014:5) mengatakan bahwa "belajar pada hakikatnya adalah perubahan yang terjadi dalam diri seseorang setelah berakhirnya melakukan aktivitas belajar".

Menurut Sardiman (2011:21) "belajar itu sebagai rangkaian kegiatan jiwa raga, psiko-fisik untuk menuju ke perkembangan pribadi manusia seutuhnya, yang berarti menyangkut unsur cipta, rasa dan karsa, ranah kognitif, afektif, dan psikomotor".

Dari pendapat para ahli diatas saya menarik kesimpulan bahwa belajar merupakan proses perubahan tingkah laku atau perilaku seseorang menjadi lebih baik lagi dengan belajar maka kita akan mendapat pengetahuan baru tetapi jika kita tidak mau belajar maka kita tidak akan mengetahui apa-apa. Itu sebabnya, dalam proses belajar guru harus dapat membimbing dan memfasilitasi siswa agar dapat melakukan proses belajar dengan baik. Jadi untuk memahami dari pesan belajar, maka dalam belajar tersebut individu menggunakan kemampuan pada ranah-ranah: 1) Kognitif yaitu kemapuan yang berkenaan dengan pengetahuan, penalaran atau pikiran terdiri dari kategori pengetahuan, pemahaman, penerapan, analisis, sintesis dan

evaluasi. 2) Afektif yaitu 
kemampuan yang mengutamakan perasaan, emosi, dan reaksi-reaksi yang berbeda dengan penalaran yang terdiri dari kategori penerimaan, partisipasi, penilaian/ penentuan sikap, organisasi, dan pembentukan pola hidup. 3) Psikomotor yaitu kemampuan yang mengutamakan keterampilan jasmani terdiri dari persepsi, kesiapan, gerakan, dan kreatifitas.

Oemar Hamalik (dalam Instarani dan Intan Pulungan,

2015:60) mengatakan bahwa "motivasi adalah perubahan energi dalam diri (pribadi) seseorang yang ditandai dengan timbulnya perasaan dan reaksi untuk mencapai tujuan".

Selanjutnya Ridwan Abdullah Sani (dalam Instarani dan

Intan Pulungan, 2015:59) mengatakan bahwa "suatu energi dalam diri manusia yang mendorong untuk melakukan aktivitas tertentu dengan tujuan tertentu".

Dari pendapat para ahli diatas saya dapat menarik kesimpulan bahwa motivasi merupakan dorongan yang terdapat dari dalam diri

seseorang untuk berusaha mengadakan perubahan tingkah laku yang lebih baik dalam memenuhi kebutuhannya.

Selanjutnya menurut Hamzah (2014:23) mengatakan "motivasi belajar adalah dorongan internal dan eksternal pada siswa-siswa yang belajar untuk mengadakan perubahan tingkah laku, pada umumnya dengan beberapa indikator pendukung".

Menurut Dimyanti dan Mudjiono (2013:78) mengatakan bahwa "motivasi belajar merupakan kekuatan mental yang mendorong terjadinya proses belajar".

Dari pendapat para ahli di atas saya menarik kesimpulan bahwa motivasi belajar merupakan dorongan yang dapat mempengaruhi siswa baik berasal dari dalam diri siswa maupun dari luar diri siswa, salah satunya adalah lingkungan belajar siswa, sehingga merasa senang dalam belajar dan merasa tidak cepat bosan menerima pelajaran yang di sampaikan oleh guru.

Wina Sanjaya (dalam Istarani, 2014:1) menyatakan "Metode adalah cara yang dapat digunakan untuk melaksanakan strategi". Metode secara harfiah berarti 'cara'. Dalam pemakaian umum, metode diartikan sebagai suatu cara atau prosedur yang dipakai untuk mencapai tujuan tertentu.

\section{Sedangkan}

Pupuh

Faturrohman (dalam Istarani, 2014:1) mengartikan metode sebagai "suatu cara atau prosedur yang dipakai untuk mencapai tujuan tertentu”.

Jadi, berdasarkan pengertian pendapat para ahli diatas saya dapat menarik kesimpulan bahwa metode pembelajaran adalah cara - cara menyajikan materi pelajaran yang dilakukan oleh pendidik agar terjadi proses belajar pada diri siswa dalam upaya untuk mencapai tujuan. Dengan demikian, salah satu keterampilan guru yang memegang peranan penting dalam proses 
pembelajaran adalah keterampilan memilih metode.

Miftahul Huda (2014:209) mengatakan bahwa "role play adalah suatu cara penguasaan bahan-bahan pelajaran melalui pengembangan imajinasi dan penghayatan siswa".

Pengembangan imajinasi dan penghayatan dilakukan siswa dengan memerankan diri sebagai tokoh hidup atau benda mati.

Sudjana (dalam Istarani
2014:70) mengatakan bahwa
"bermain peran merupakan suatu
kegiatan pembelajaran yang
menekankan pada kemampuan penampilan peserta didik untuk memerankan status dan fungsi pihakpihak lain yang terdapat pada kehidupan nyata."

Dari uraian di atas saya menyimpulkan bahwa role play sangat penting manfaatnya dalam pembelajaran. Role play dalam pelaksanaannya membuat siswa memperoleh sebuah tugas dari guru untuk mendramatisasikan suatu situasi sosial yang mengandung suatu problem, agar peserta didik dapat memecahkan suatu masalah yang muncul dari suatu situasi sosial.

\section{METODE}

PENELITIAN

Penelitian ini dilakukan di

SD Swasta Xaverius Padang sidimpuan T.A 2015/2016. Jenis penelitian ini adalah penelitian tindakan kelas (PTK) yang bertujuan untuk meningkatkan hasil belajar siswa. Subjek dalam penelitian ini adalah siswa kelas IV SD Swasta Xaverius Padangsidimpuan T.A
2015/2016 yang berjumlah 43 orang siswa. Dengan jumlah siswa laki-laki sebanyak 21 orang dan siswa perempuan 22 orang. Adapun yang menjadi variabel penelitian adalah motivasi belajar siswa dan metode pembelajaran Role Play.

Sesuai dengan jenis penelitian tindakan kelas, maka penelitian ini memiliki beberapa tahapan yang merupakan suatu siklus. Tiap siklus dilaksanakan berdasarkan perubahan yang akan dicapai. Pada penelitian ini akan dilaksanakan dalam dua siklus yakni siklus I dan siklus II. Prosedur Penelitian ini menggunakan beberapa

tahapan yakni dimulai dari perencanaan, pelaksanaan tindakan, pengamatan dan terakhir refleksi. Alat pengumpulan data yang digunakan pada penelitian ini adalah observasi dan angket.

\section{Siklus I}

Pada tahap perencanaan ini, peneliti mengadakan konsultasi

terhadap guru kelas tentang pelaksanaan penelitian tindakan kelas yang akan dilakukan peneliti, sehingga guru dapat bekerja sama dengan peneliti dalam melaksanakan penelitian ini. Pada tahap ini kegiatan yang dilakukan yaitu:

a. Mempersiapkan rencana pelaksanaan pembelajaran (RPP) dengan materi ajar membaca pantun

b. Membuat lembar observasi, guna mengamati proses pembelajaran. 
c. Menyusun alat evaluasi berupa soal/ pertanyaan untuk mengetahui tingkat keberhasilan yang dicapai siswa dalam setiap siklus dengan diterapkannya metode pembelajaran role play dalam proses pembelajaran.

d. Memepersiapkan contoh skenario

Tahap tindakan merupakan tahap yang dilakukan oleh guru/peneliti sebagai upaya perbaikan, peningkatan atau perubahan yang diinginkan. Adapun tahap pelaksanaan tindakan sebagai berikut:

a. Memberi salam dan berdoa sebelum kegiatan belajar dimulai $b$.

Menjelaskan secara singkat menggunakan metode pembelajaran role play

c. Menyampaikan materi yang akan diajarkan dengan ceramah yang interaktif

d. Peneliti membentuk kelompok yang beranggotakan 4-5 orang dalalm satu kelompok

e. Memberi kesempatan kepada siswa untuk mempelajari skenario yang telah dibagikan

f. Meminta siswa untuk memperagakan role play di depan kelas

g. Guru memberikan kesimpulan materi pelajaran

h. Siswa diberi latihan berupa soalsoal

Tahap ini merupakan kegiatan pengamatan atas hasil atau dampak dari tindakan yang dilaksanakan atau dikenakan terhadap siswa. Dalam pelaksanaannya guru/peneliti mengamati proses belajar mengajar dengan mengacu pada lembar observasi yang telah disiapkan terlebih dahulu, untuk mengetahui sejauhmana tindakan tersebut dapat merangsang siswa.

Tahap ini merupakan kegiatan mengkaji, melihat dan mempertimbangkan hasil atau dampak dari tindakan. Berdasarkan dari hasil refleksi ini akan terlihat motivasi belajar siswa. Apabila terlihat masilih banyak yang mengalami kesulitan atau belum mencapai standar kriteria ketuntasan minimal (KKM) maka peneliti merencanakan tahap tindakan kedua pada siklus kedua.

\section{Siklus II}

Dari hasil refleksi pada siklus I peneliti kembali merancang untuk Rencana Pelaksanaan Pembelajran (RPP). Pada tahap ini perencanaan disusun sebagai berikut:

a. Mempersiapkan rencana pelaksanaan pembelajaran dengan materi ajar masalahmasalah sosial

b. Membuat lembar observasi, guna mengamati proses pembelajaran.

c. Menyusun alat evaluasi berupa soal/ pertanyaan untuk mengetahui tingkat keberhasilan yang dicapai siswa dalam setiap siklus dengan diterapkannya 
Wesly Silalahi : Upaya Meningkatkan Motivasi ...

metode pembelajaran role play dalam proses pembelajaran.

d. Memepersiapkan skenario

Tahap tindakan merupakan tahap yang dilakukan oleh guru/peneliti sebagai upaya perbaikan, peningkatan atau perubahan yang diinginkan. Adapun tahap pelaksanaan tindakan sebagai berikut:

a. Siswa diberikan motivasi sebelum memulai pelajaran

b. Siswa mendengarkan penjelasan materi dari guru

c. Siswa diberi waktu untuk memahami materi pelajaran

d. Peneliti membentuk kelompok yang beranggotakan 4-5 orang dalalm satu kelompok

e. Siswa memperagakan role play di depan kelas

f. Guru memberikan kesimpulan

g. Siswa diberi soal-soal latihan
Tahap observasi merupakan tahap dimana peneliti memonitoring proses pembelajaran yang sedang berlangsung dan memberi angket.

Kegiatan ini dilakukan untuk mengetahui perbandingan hasil antara siklus I dan siklus II. Apabila pada siklus II hasil belajar anak meningkat dan mencapai standar nilai yang telah ditentukan maka proses penelitian dapat dihentikan.

\section{HASIL PENELITIAN DAN PEMBAHASAN}

Berdasarkan dari hasil penyebaran angket, dapat dilihat bahwa terdapat suatu peningkatan dan perubahan secara signifikan terhadap motivasi belajar siswa dengan menggunakan metode role play. Dapat dilihat pada tabel 4.17 untuk mengetahui bentuk suatu peningkatan dan perubahan motivasi belajar siswa.

Tabel 1. Perbandingan Motivasi Belajar Siswa Pada Siklus I dan Siklus II

\begin{tabular}{c|c|c|c|c|c|c}
\hline \multirow{2}{*}{ No. } & No. & \multicolumn{2}{|c|}{ Siklus I } & \multicolumn{2}{|c|}{ Siklus II } & \multirow{2}{*}{ Keterangan } \\
\cline { 3 - 6 } & Responden & P1 & P2 & P1 & P2 & Meningkat \\
\hline 1 & 001 & 47 & 76 & 84 & 84 & Meningkat \\
\hline 2 & 002 & 51 & 76 & 83 & 85 & Meningkat \\
\hline 3 & 003 & 53 & 78 & 84 & 85 & Meningkat \\
\hline 4 & 004 & 61 & 78 & 84 & 85 & Meningkat \\
\hline 5 & 005 & 59 & 78 & 84 & 82 & Meningkat \\
\hline 6 & 006 & 63 & 76 & 83 & 81 & Meningkat \\
\hline 7 & 007 & 62 & 81 & 84 & 86 & Meningkat \\
\hline 8 & 008 & 56 & 75 & 84 & 87 & Meningkat \\
\hline 9 & 009 & 56 & 69 & 82 & 90 & Meningkat \\
\hline 10 & 010 & 75 & 75 & 83 & 90 & Meningkat \\
\hline 11 & 011 & 73 & 76 & 82 & 90 & Meningkat \\
\hline 12 & 012 & 58 & 70 & 83 & 84 & Meningkat \\
\hline 13 & 013 & 52 & 75 & 85 & 86 & Meningkat \\
\hline 14 & 014 & 53 & 74 & 74 & 82 & \\
\hline 15 & 015 & 58 & 78 & 83 & 89 & \\
\hline 16 & 016 & 54 & 75 & 83 & 88 & \\
\hline
\end{tabular}


SCHOOL EDUCATION JOURNAL VOLUME 8 NO. 2 JUNI 2018

\begin{tabular}{|c|c|c|c|c|c|c|}
\hline 17 & 017 & 73 & 79 & 83 & 87 & Meningkat \\
\hline 18 & 018 & 51 & 78 & 83 & 91 & Meningkat \\
\hline 19 & 019 & 56 & 73 & 84 & 92 & Meningkat \\
\hline 20 & 020 & 74 & 82 & 86 & 98 & Meningkat \\
\hline 21 & 021 & 50 & 62 & 74 & 83 & Meningkat \\
\hline 22 & 022 & 71 & 78 & 84 & 86 & Meningkat \\
\hline 23 & 023 & 72 & 78 & 83 & 90 & Meningkat \\
\hline 24 & 024 & 53 & 74 & 74 & 83 & Meningkat \\
\hline 25 & 025 & 49 & 74 & 74 & 86 & Meningkat \\
\hline 26 & 026 & 75 & 77 & 83 & 88 & Meningkat \\
\hline 27 & 027 & 71 & 78 & 84 & 98 & Meningkat \\
\hline 28 & 028 & 81 & 77 & 84 & 88 & Meningkat \\
\hline 29 & 029 & 39 & 77 & 74 & 86 & Meningkat \\
\hline 30 & 030 & 45 & 77 & 83 & 85 & Meningkat \\
\hline 31 & 031 & 41 & 62 & 74 & 81 & Meningkat \\
\hline 32 & 032 & 45 & 72 & 81 & 90 & Meningkat \\
\hline 33 & 033 & 46 & 75 & 84 & 90 & Meningkat \\
\hline 34 & 034 & 50 & 75 & 74 & 85 & Meningkat \\
\hline 35 & 035 & 56 & 76 & 83 & 91 & Meningkat \\
\hline 36 & 036 & 61 & 74 & 81 & 88 & Meningkat \\
\hline 37 & 037 & 73 & 75 & 83 & 87 & Meningkat \\
\hline 38 & 038 & 54 & 78 & 82 & 91 & Meningkat \\
\hline 39 & 039 & 47 & 63 & 74 & 85 & Meningkat \\
\hline 40 & 040 & 42 & 70 & 72 & 74 & Tetap \\
\hline 41 & 041 & 47 & 74 & 84 & 87 & Meningkat \\
\hline 42 & 042 & 56 & 74 & 74 & 84 & Meningkat \\
\hline 43 & 043 & 54 & 73 & 74 & 83 & Meningkat \\
\hline
\end{tabular}

Secara klasikal motivasi belajar siswa adalah $86,76 \%$ sehingga secara klasikal telah dapat mencapai keberhasilan. Hasil observasi siswa dan guru mengalami peningkatan siklus II. Berdasarkan keterangan diatas dapat disimpulkan aktifitas yang terjadi di dalam kelas meningkat sehingga meningkatkan motivasi belajar siswa. Setelah dilakukan tindakan pembelajaran dengan menggunakan metode role play diperoleh peningkatan motivasi belajar siswa siswa sebesar $86,76 \%$ atau 37 orang telah termotivasi dalam belajarnya. Hal ini berarti meningkatkan keterampilan bertanya siswa telah berhasil. Oleh karena itu metode role play efektif digunakan dalam meningkatkan motivasi belajar siswa dalam materi pokok masalahmasalah sosial.

Tabel 2. Deskripsi Observasi Motivasi Belajar Siswa

\begin{tabular}{|c|c|c|c|c|c|}
\hline \multirow[t]{2}{*}{ No } & \multirow{2}{*}{$\begin{array}{c}\text { Pencapaian Keterampilan } \\
\text { Bertanya Siswa }\end{array}$} & \multicolumn{2}{|c|}{ Siklus I } & \multicolumn{2}{|c|}{ Siklus II } \\
\hline & & $\mathbf{P 1}$ & $\mathbf{P 2}$ & $\mathbf{P 1}$ & $\mathbf{P 2}$ \\
\hline 1 & Nilai rata-rata & 57,23 & 74,76 & 80,83 & 86,76 \\
\hline 2 & Jumlah siswa yang termotivasi & 10 & 29 & 32 & 42 \\
\hline 3 & Persentase Keberhasilan & $23 \%$ & $67 \%$ & $74 \%$ & $98 \%$ \\
\hline
\end{tabular}



Dengan peningkatan motivasi belajar siswa yang telah diperoleh siswa dari siklus I dan sampai dilakukannya siklus II ini telah terjadi peningkatan yang cukup signifikan. Peneliti merasa telah cukup memenuhi persentase klasikal sesuai dengan harapan peneliti.

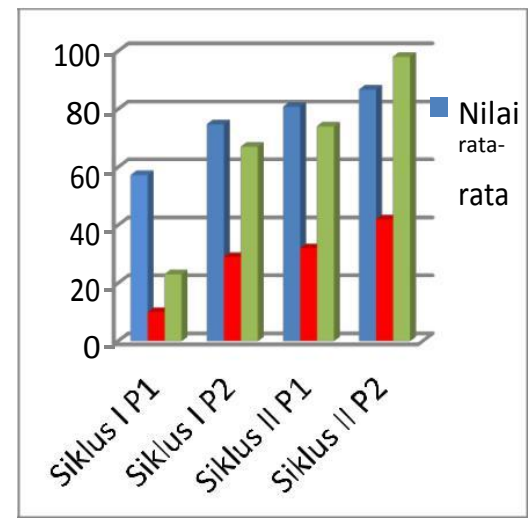

Grafik 1. Perbandingan Obsesvasi Motivasi Belajar Siswa Siklus I , Siklus II

Tabel 3. Deskripsi Angket Motivasi Belajar Siswa

\begin{tabular}{c|l|c|c}
\hline \multirow{2}{*}{ No } & \multirow{2}{*}{ Pencapaian Motivasi Siswa } & \multicolumn{2}{|c}{ Angket } \\
\cline { 3 - 4 } & & Kondisi Awal & Pasca Siklus II \\
\hline 1 & Nilai rata-rata & 64,16 & 90,95 \\
\hline 2 & Jumlah siswa yang termotivasi & 6 & 42 \\
\hline 3 & Persentase keberhasilan & $14 \%$ & $98 \%$ \\
\hline
\end{tabular}

Pada angket kondisi awal mengalami peningkatan yang cukup signifikan. peneliti merasa telah cukup memenuhi keberhasilan klasikal sebesar $98 \%$ sesuai dengan harapan peneliti.

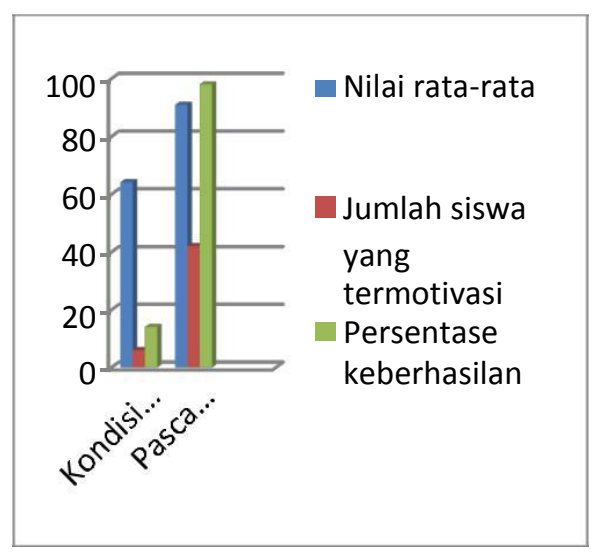

Grafik 2. Perbandingan Angket Motivasi Belajar Siswa

\section{SIMPULAN}

Berdasarkan hasil dan pembahasan penelitian yang telah dilakukan pada pelajaran Ilmu

Pengetahuan Sosial dengan menggunakan metode role play kelas IV SD Swasta Xaverius Padangsidimpuan, maka dapat ditarik kesimpulan sebagai berikut:

a. Motivasi belajar siswa kelas IV

SD Swasta Xavrius

Padangsidimpuan pada pelajaran Ilmu Pengetahuan Sosial pokok bahasan masalah-masalah sosial dengan menggunakan metode role play telah mengalami perubahan dan peningkatan dibandingkan sebelum dilakukannya metode ini. 
b. Dengan menggunakan metode role play telah memberikan ketertarikan serta keikutsertaan dan partisipasi siswa dalam kegiatan pembelajaran yang dilakukan.

c. Dari hasil penelitian yang telah dilakukan oleh peneliti, dapat diketahui dari rata-rata motivasi belajar siswa secara individu pada setiap siklus dan pertemuan padapelajaranIlmu

Pengetahuan Sosial pokok bahasan masalah-masalah sosial mengalami peningkatan dari Siklus I pertemuan I sebesar $57,23 \%$, Siklus I pertemuan II sebesar 74,76\%, Siklus II pertemuan I sebesar 80,83\%, Siklus II pertemuan II sebesar $86,76 \%$. Pada observasi guru Siklus I Pertemuan I sebesar 67,64\% (cukup baik), Siklus I Perremuan II sebesar 72,05\% (baik), Siklus II Pertemuan I sebesar 76,47\% (baik), Siklus II Pertemuan II sebesar $89,70 \%$ (sangat baik).

\section{DAFTAR RUJUKAN}

Dewi, Rosmala. 2014.

Profesionalisasi Guru Melalui

Penelitian Tindakan Kelas.

Medan: Pasca Sarjana Unimed.

Dimyati dan Mudjino. 2013. Belajar dan Pembelajaran. Jakarta: Rineka Cipta.

Dirman, Cicih. 2014. Teori Belajar

dan Prinsip-Prinsip

Pembelajaran yang Menarik. Jakarta: Rineka Cipta.
Gunawan, Rudy. 2011. Pendidikan IPS Filosofi, Konsep dan Aplikasi. Bandung: Afabeta.

Istarani. 2014. 58 Model Pembelajaran Inovatif. Medan: Media Persada.

Istarani, Intan. 2015. Esiklopedi Pendidikan. Medan: Media Persada.

Miftahul. 2014. Model-Model Pengajaran dan Pembelajaran. Yogyakarta: Pustaka Belajar.

Sardiman.2014. Interaksi dan Motivasi Belajar Mengajar. Jakarta: Rajawali.

Slameto. 2010. Belajar dan Faktorfaktor yang Mempengaruhi. Jakarta: Rineka Cipta.

Sumiati, Asra. 2013. Metode Pembelajaran. Bandung: Bumi Rancaekek Kencana.

Trianto. 2009. Mendesain Model Pembelajaran InovatifProgresif. Jakarta: Kencana.

Trianto. 2010. Model Pembelajaran Terpadu. Jakarta: Bumi Aksara.

Uno, Hamzah. 2014. Teori Motivaasi dan Pengukurannya. Jakarta: Bumi Aksara. 